\title{
APLIKASI METODE ANALYSIS OF VARIANCE (ANOVA) UNTUK MENGKAJI PENGARUH PENAMBAHAN SILICA FUME TERHADAP SIFAT FISIK DAN MEKANIK MORTAR
}

\author{
Jauhar Fajrin ${ }^{1}$, Pathurahman ${ }^{2}$, Lalu Gita Pratama ${ }^{3}$
}

\begin{abstract}
ABSTRAK
Penelitian yang berkaitan dengan penambahan bahan pozolan untuk memperbaiki mutu mortar atau beton sudah cukup banyak dilakukan. Namun demikian, penelitian-penelitian terdahulu umumnya dilakukan dengan menggunakan metode yang berbasis pada standar. Kelemahan metode ini adalah kesimpulan yang diambil hanya berdasarkan statistik deskriptif tanpa melibatkan proses pengujian hipotesis menggunakan statistik inferensial. Tujuan dari penelitian ini adalah untuk mengetahui pengaruh penambahan bahan pozolan silica fume terhadap karakteristik fisik dan mekanik mortar dengan mengaplikasikan metode analysis of variance (ANOVA). Metode yang digunakan dalam penelitian ini adalah metode eksperimen murni dimana percobaan laboratoriumnya didesain sebagai single factor experiment. Kesimpulan yang bisa diambil dari penelitian adalah: 1) Penambahan bahan pozolan silica fume mampu membuat mortar menjadi lebih kedap air yang ditandai dengan menurunnya daya serap air seiring dengan bertambahnya proporsi silica fume sebagai pengganti sebagian semen. Terjadi penurunan daya serap air sebesar 18,3\% ketika mortar diberi tambahan silica fume sebesar 3\% dari berat semen. Selanjutnya terjadi penurunan secara konstan sebesar 22,7\%, 33,2\% dan $35,2 \%$ ketika ditambahkan silica fume sebesar 5,7 dan $10 \%$. 2) Penambahan silica fume juga mampu menurunkan $\mathrm{pH}$ mortar. Tetapi pada penelitian ini, meskipun $\mathrm{pH}$ mortar menurun dengan bertambahnya proporsi silica fume, kondisi $\mathrm{pH}$ nya masih dalam keadaan basa yang relatif aman bagi tulangan yang dilindungi oleh mortar. 3) Untuk sifat mekanik, terlihat bahwa kuat tekan mortar berbanding lurus dengan peningkatan kandungan silica fume yang dicampurkan. Rata-rata kuat tekan mortar normal tanpa campuran silica fume adalah 39,9 MPa. Sementara kuat tekan rata-rata mortar dengan campuran silica fume secara berturut-turut adalah 40,4 MPa, 42,3 MPa, 43,2 MPa dan 45,1 MPa atau terjadi peningkatan kuat tekan berturut-turut sebesar $1,1 \%, 5,9 \%, 8,2 \%$, dan $12,8 \%$ untuk proporsi $3,5,7$ dan $10 \%$.
\end{abstract}

Kata Kunci: mortar, silica fume, analysis of variance, karakteristik mortar, single factor analysis

\section{PENDAhuluaN}

Tipikal konstruksi dinding di Indonesia adalah sebuah dinding bata satu lapis dimana bata-bata tersebut direkatkan satu sama lain dengan menggunakan adonan semen dan pasir yang dilindungi oleh lapisan pelindung yang dinamakan 'plesteran' dimana untuk istilah dunia konstruksinya disebut mortar. Mortar berfungsi sebagai pelindung bagi batu bata atau tulangan yang tertanam didalamnya, biasanya motar digunakan pada proses akhir (finishing) dari proses pembangunan. Untuk itu mortar menjadi bagian terluar dari susunan dinding yang akan melakukan kontak secara langsung dengan

${ }^{1}$ Dosen Jurusan Teknik Sipil, Fakultas Teknik, Universitas Mataram ( jauhar.fajrin@unram.ac.id

${ }^{2}$ Dosen Jurusan Teknik Sipil, Fakultas Teknik, Universitas Mataram (pathurahman@unram.ac.id)

${ }^{3}$ Alumni Jurusan Teknik Sipil, Fakultas Teknik, Universitas Mataram (gita.pratama@gmail.com) 
lingkungan tempat bangunan tersebut berada. Salah satu masalah yang sering terjadi di Indonesia, khususnya pada bangunan yang berada pada daerah agresif seperti pesisir pantai, adalah cepat berkaratnya tulangan atau terdegradasinya bata akibat tidak mendapatkan perlindungan yang cukup dari mortar sebagai bagian terluar. Permasalahan tersebut tidak lepas dari kebiasaan masyarakat yang suka meniru begitu saja praktek pembangunan rumah permanen untuk daerah non agresif yang diterapkan di daerah agresif. Bahan plesteran atau mortar yang diperuntukan untuk daerah non agresif apabila digunakan di daerah agresif akan menyebabkan durabilitas mortar tersebut berkurang. Untuk itu mortar cepat rusak dan tidak mampu melindungi bata dan tulangan yang berada didalamnya. Jangka panjangnya bangunan tersebut akan cepat rusak. Oleh karena itu mortar perlu mempunyai durabilitas yang tinggi, apabila bangunan tersebut berada pada lingkungan yang memiliki daya rusak yang tinggi. Mortar yang baik untuk daerah agresif adalah mortar yang mampu menahan masuknya unsur kimia di dalam air yang bersifat menyerang kekuatan mortar tersebut. Selain itu mortar juga harus mempunyai kekuatan tekan yang tinggi dan permeabilitas yang rendah.

Penelitian terdahulu menunjukkan bahwa penambahan bahan yang bersifat pozzolan sebagai pengganti semen pada campuran mortar mampu menambah kekuatan maupun durabilitasnya. Penambahan bahan yang bersifat pozzolan ini sebenarnya telah banyak diteliti baik pada campuran beton ataupun mortar untuk menambah kekuatannya. Ilham (2005) dalam penelitiannya tentang pengaruh sifat-sifat fisik dan kimia bahan pozzolan pada beton kinerja tinggi menyatakan bahwa beton dengan campuran silica fume menunjukan pencapaian kuat tekan melebihi yang direncanakan pada umur 28 hari. Kuat tekannya mencapai antara 100-110\% dengan kuat tekan rencana 50, 60, 70, dan $80 \mathrm{MPa}$. Selanjutnya, Afif (2013) dalam penelitiannya tentang pengaruh penambahan silica fume dengan superplasticizer dengan pemakaian semen tipe PPC dan tipe PCC terhadap peningkatan mutu beton menyatakan bahwa kuat tekan tertinggi dicapai pada sampel beton PPC dengan kandungan silica fume 5\% dan superplasticizer 2\% dengan umur 56 hari sebesar $54.16 \mathrm{Mpa}$

Meskipun mortar dan beton adalah dua material yang berbeda, tetapi sebetulnya hampir sama karena beton adalah mortar yang kemudian didalamnya dicampurkan dengan agregat kasar (kerikil/batu pecah). Sehingga pembahasan tentang mortar bisa juga mengacu pada kajian-kajian mengenai beton. Samekto dan Rahmadiyanto (2001) menjelaskan bahwa zat kimia dapat mengakibatkan kerusakan pada beton, sebagian atau secara keseluruhan. Adanya kerusakan tersebut terutama disebabkan oleh terjadinya reaksi antara alkali dari semen dengan zat penyerangnya, atau dengan yang ada dalam beton itu sendiri. Karena semen merupakan zat yang alkalis (basa), dengan sendirinya beton tidak tahan terhadap pengaruh asam. Pasta semen yang bersifat basa tadi, oleh pengaruh asam akan rusak dan hilang daya rekatnya, sehingga beton menjadi rusak. Lebih lanjut dikatakan oleh Samekto dan Rahmadiyanto (2001) bahwa untuk mencegah atau mengurangi terjadinya kerusakan seperti itu, dapat dilakukan terutama dengan membuat beton yang padat (kedap air) dan/atau melindungi permukaan beton dengan zat lain yang dapat menahan pengaruh zat asam perusak tersebut. Dari sekian banyak senyawa asam yang dapat merusak, yang paling banyak dan sering dilakukan penjagaan terhadapnya adalah senyawa sulfat. Garam-garam sulfat biasanya terdapat di dalam air, dan juga terdapat di dalam tanah dan di laut, atau danau dan rawa-rawa. Sulfat ini, dengan semen yang berkadar $\mathrm{C}_{3} \mathrm{~A}$ cukup tinggi, akan bersenyawa membentuk kuman semen (cement bacilus) yang rapuh dan membesar, sehingga lama kelamaan gugur dan rusak.

Namun demikian, penelitian-penelitian terdahulu umumnya dilakukan dengan menggunakan metode yang berbasis pada standar (standardized test procedures). Kelemahan metode ini adalah kesimpulan yang diambil hanya berdasarkan statistik deskriptif tanpa melibatkan proses pengujian hipotesis menggunakan statistik inferensial. Tujuan dari penelitian ini adalah untuk mengetahui pengaruh penambahan bahan pozolan silica fume terhadap karatareistik fisik dan mekanik mortar dengan mengaplikasikan metode analysis of variance (ANOVA). Pengaplikasian metode statistik ini dimaksudkan untuk menghasilkan kesimpulan yang lebih akurat dan terencana. Melalui metode ini, analisis data dapat dilakukan secara mendalam dengan tidak hanya membandingkan nilai rata-rata

\section{2 | JURNAL REKAYASA SIPIL}


dari setiap perlakuan, tetapi juga membandingkan setiap variasi yang ada pada setiap sampel yang diuji. Penelitian akan melibatkan kajian-kajian statistik teoritis dan juga menggunakan software statistik yakni, Minitab 14.

\section{METODE ANALYSIS OF VARIANCE (ANOVA)}

Statistika adalah ilmu atau seni yang berkaitan dengan tata cara (metode) pengumpulan data, analisis data, dan interpretasi hasil analisis untuk mendapatkan informasi guna penarikan kesimpulan dan pengambilan keputusan. Metode statistik yang banyak digunakan untuk menganalisis data dari suatu percobaan yang terancang adalah teknik analisis ragam atau sering disebut dengan ANOVA. Analisis ragam adalah sebuah metode untuk memeriksa hubungan antara dua atau lebih set data. Dengan kata lain ada hubungan antara set data dengan melakukan analisis varians. Analisis varian kadang- kadang disebut sebagai F-test. Suatu ciri analisis ragam adalah model ini terparameterisasikan secara berlebih, artinya model ini mengandung lebih banyak parameter dari pada yang dibutuhkan untuk mempresentasikan pengaruh-pengaruh yang diinginkan. Salah satu tipe dari analisis ragam adalah analisis varians satu jalur atau juga dikenal dengan istilah one-way ANOVA.

Analisis varians satu jalur adalah proses menganalisis data yang diperoleh dari percobaan dengan berbagai tingkat faktor, biasanya lebih dari dua tingkat faktor. Tujuan dari analisis ini adalah untuk mengindentifikasi variabel bebas yang penting dan bagaimana variabel tersebut dapat mempengaruhi respons (Wackerley, 2008 dalam Fajrin, 2011). Bila hanya salah satu faktor yang diselidiki, proses ini disebut satu arah atau analisis varians satu jalur. Model untuk analisis ini dijabarkan sebagai berikut.

$$
y_{i j}=\mu+\tau_{i}+\epsilon_{i j}\left\{\begin{array}{l}
i=1,2, \ldots, a \\
j=1,2, \ldots, n_{i}
\end{array}\right.
$$

dengan,

$\mathrm{y}_{\mathrm{ij}} \quad$ : Pengamatan ke j dalam kelompok ke i

$\mu \quad$ : Nilai tengah sering disebut dengan rerata umum

$\tau_{\mathrm{i}} \quad$ : Parameter yang menyatakan rerata kelompok ke i

$\epsilon_{\mathrm{ij}} \quad$ : Galat pada pengamatan ke $(\mathrm{i}, \mathrm{j})$

Hipotesis nol dan alternatif untuk analisis statistik ini,

$$
\begin{aligned}
& \mathrm{H}_{0}=\mu_{1}=\mu_{2}=\ldots . .=\mu_{\mathrm{a}} \text { atau secara ekuivalen, } \mathrm{H}_{0}=\tau_{1}=\tau_{2}=\ldots . .=\tau_{\mathrm{a}}=0 \\
& \mathrm{H}_{1}=\mu_{\mathrm{i}} \neq \mu_{\mathrm{j}} \text { untuk setidaknya satu pasangan }(\mathrm{i}, \mathrm{j}) .
\end{aligned}
$$

Prosedur berikutnya untuk proses analisis ini adalah untuk menghitung:

$$
\begin{aligned}
& \mathrm{SS}_{\mathrm{T}}=\sum_{\mathrm{i}=1}^{\mathrm{a}} \sum_{\mathrm{j}=1}^{\mathrm{n}}\left(\mathrm{y}_{\mathrm{ij}}-\overline{\mathrm{y}}_{. . .}\right)^{2} \\
& \mathrm{SS}_{\mathrm{t}}=\mathrm{SS}_{\text {treatments }}+\mathrm{SS}_{\mathrm{E}} \\
& \mathrm{MS}_{\text {treatments }}=\frac{\mathrm{SS}_{\text {treatments }}}{\mathrm{a}-1} \\
& \mathrm{MS}_{\mathrm{E}}=\frac{\mathrm{SS}_{\mathrm{E}}}{(\mathrm{N}-\mathrm{a})}
\end{aligned}
$$


Kemudian dilakukan uji statistik dengan menggunakan persamaan berikut ini:

$$
\mathrm{F}_{0}=\frac{\mathrm{SS}_{\text {treatments }} /(\mathrm{a}-1)}{\mathrm{SS}_{\mathrm{E}} /(\mathrm{N}-\mathrm{a})}=\frac{\mathrm{MS}_{\text {treatments }}}{\mathrm{MS}_{\mathrm{E}}}
$$

Dengan:

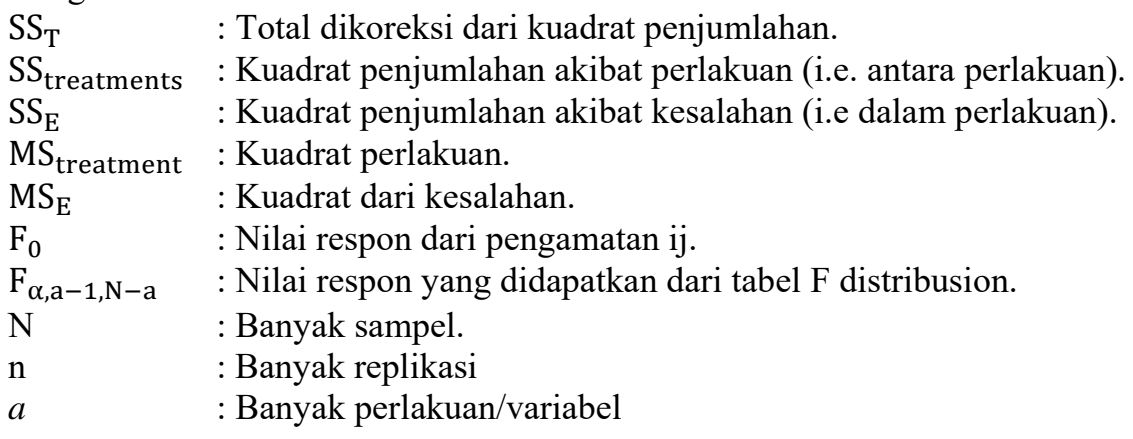

Hipotesis nol $\left(H_{0}\right)$ harus ditolak dan disimpulkan bahwa terdapat perbedaan yang signifikan diantara variabel penelitian jika:

$$
\mathrm{F}_{0}>\mathrm{F}_{\propto, \mathrm{a}-1, \mathrm{n}-\mathrm{a}}
$$

Selain melakukan perhitungan teoritis, juga dilakukan analisa dengan menggunakan software statistik, yakni MINITAB 14. MINITAB merupakan salah satu program aplikasi statistika yang banyak digunakan untuk mempermudah pengolahan data statistik.

\section{METODE PENELITIAN}

Metode yang digunakan dalam penelitian ini adalah metode eksperimen murni dimana percobaan laboratoriumnya didesain sebagai single factor experiment. Hasil eksperimen kemudian dianalisis menggunakan metode one-way ANOVA. Metode ini dipercaya sebagai metode penelitian yang paling akurat dalam melakukan eksperimen yang berusaha membuktikan atau menolak hipotesis secara matematika dengan menggunakan analisa statistik. Hal yang menonjol dari metode ini adalah adanya variabel dan kontrol grup (Shuttleworth, 2008). Kontrol adalah perlakuan yang dijadikan sebagai standar (benchmark) untuk mengevaluasi efektifitas dari perlakuan-perlakuan yang diberikan dalam eksperimen (Kuehl, 2000).

Bahan-bahan yang digunakan untuk pembuatan mortar dalam eksperimen ini meliputi semen PPC, pasir, air dan bahan pozzolan yaitu silica fume. Berdasarkan hasil eksperimen pendahuluan diketahui bahwa komposisi campuran mortar yang mempunyai kinerja paling optimum adalah sebesar $30 \%$ semen dan $70 \%$ pasir. Komposisi ini selanjutnya dijadikan sebagai kontrol. Selanjutnya ditambahkan silica fume sebesar 3, 5, 7 dan 10\% dari berat semen kedalam campuran mortar dengan perbandingan yag sudah disebutkan diatas. Faktor air semen yang yang digunakan adalah sebesar 0.45 sesuai dengan proporsi optimum yang didapatkan pada eksperimen pendahuluan. Benda uji yang telah disiapkan kemudian direndam dalam air laut selama 28 hari untuk menciptakan kondisi agresif. Selengkapnya komposisi campuran diperlihatkan pada Tabel 1. Karateristik fisik dan mekanik mortar yang akan diuji adalah daya serap air, PH dan kuat tekan. Proses eksperimen dilakukan di Laboratorium Struktur dan Bahan Jurusan Teknik Sipil Universitas Mataram dan Laboratorium Kimia Analitik Fakultas MIPA Universitas Mataram.

\section{4 | JURNAL REKAYASA SIPIL}


Tabel 1. Komposisi campuran mortar yang digunakan dalam penelitian

\begin{tabular}{lccc}
\hline Mortar & $\begin{array}{c}\text { Kandungan silica fume (prosentase } \\
\text { terhadap proporsi semen) }\end{array}$ & $\begin{array}{c}\text { Berat aktual } \\
\text { semen (gr) }\end{array}$ & $\begin{array}{c}\text { Berat aktual silica } \\
\text { fume (gr) }\end{array}$ \\
\hline Kontrol & 0 & 600 & 0 \\
\hline Variabel 1 & 3 & 582 & 18 \\
\hline Variabel 2 & 5 & 570 & 30 \\
\hline Variabel 3 & 7 & 558 & 42 \\
\hline Variabel 4 & 10 & 540 & 60 \\
\hline
\end{tabular}

\section{HASIL DAN PEMBAHASAN}

\subsection{Hasil Pengujian Daya Serap Air Mortar}

Pengujian daya serap air mortar dilakukan dengan cara merendam benda uji yang sudah berumur 28 hari didalam air selama 24 jam kemudian permukaannya dikeringkan sehingga tidak ada lagi air yang menetes lalu ditimbang beratnya. Kemudian benda uji di masukkan ke dalam oven dengan suhu $110^{\circ}$ selama 24 jam kemudian ditimbang lagi. Hasil pengujian daya serap air mortar umur 28 hari dapat dilihat pada Gambar 1.

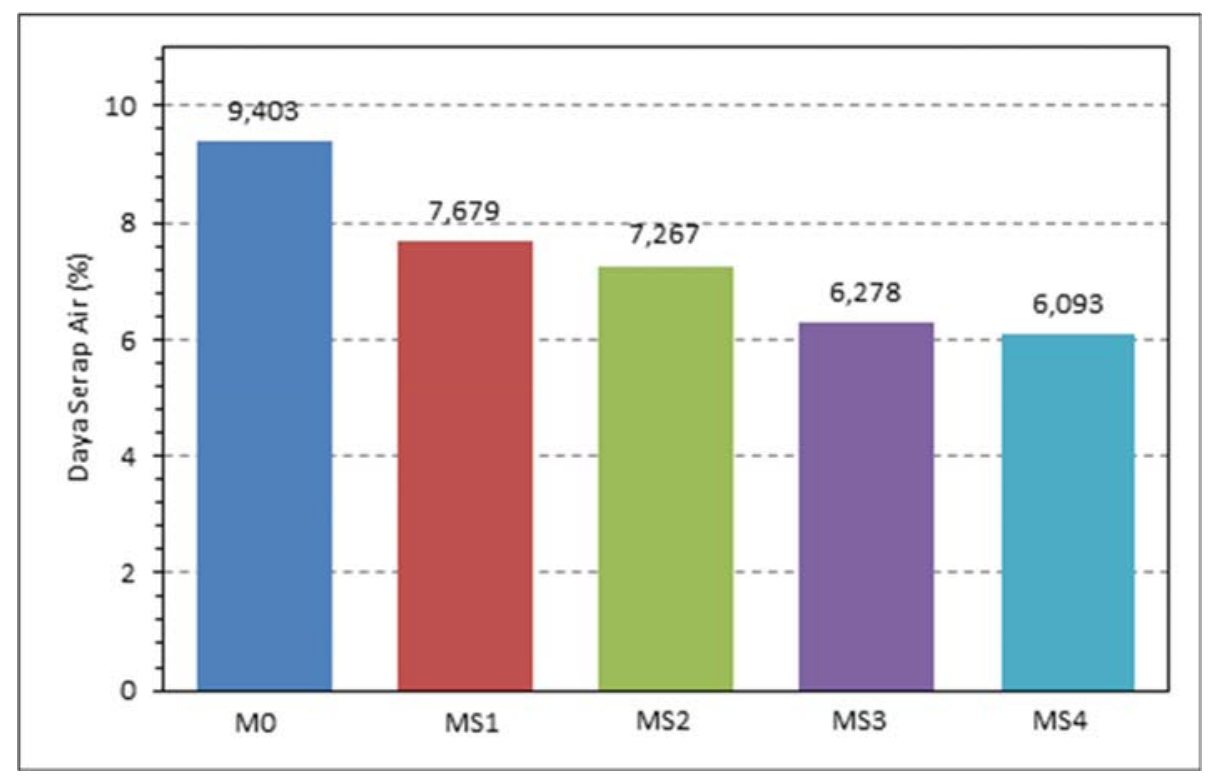

Gambar 1. Rata-rata hasil pengujian daya serap air mortar untuk masing-masing variabel penelitian

Seperti yang terlihat pada Gambar 1, penambahan silica fume mampu menurunkan daya serap air oleh mortar yang berarti meningkatkan kekedapan mortar dalam menyerap air. Rata-rata daya serap air untuk mortar normal yang tidak dicampur dengan silica fume adalah 9,402\%, diikuti secara berturut-turut oleh MS1, MS2, MS3, MS4 dengan nilai rata-rata masing-masing sebesar $7.679 \%$, $7.267 \%, 6.278 \%$, dan $6.093 \%$. Terjadi penurunan daya serap air sebesar $18,335 \%$ ketika mortar diberi tambahan silica fume sebesar 3\% dari berat semen. Selanjutnya terjadi penurunan secara konstan sebesar $22.716 \%, 33.234 \%$ dan $35.202 \%$ ketika ditambahkan silica fume sebesar 5, 7 dan $10 \%$. Peningkatan kekedapan air ini dimungkinkan karena butiran silica fume lebih kecil dari semen sehingga mampu menutupi rongga-rongga dalam mortar. Semakin banyak kandungan silica fume dalam campuran mortar berpengaruh semakin kecil pula porositas yang terjadi dalam mortar. Selanjutnya dilakukan analisa statistik menggunakan ANOVA untuk mengetahui tingkat signifikansi 
perbedaan antar variabel penelitian. Untuk itu diperlukan data lengkap mengenai hasil pengujian daya serap air seperti yang ditampilkan pada Tabel 2.

Tabel 2. Hasil pengujian daya serap air mortar

\begin{tabular}{lccccc}
\hline \multirow{2}{*}{ Variabel } & \multicolumn{3}{c}{ Daya Serap Air Mortar (\%) } & \multirow{2}{*}{ Total } & \multirow{2}{*}{ Rata-Rata (\%) } \\
\cline { 2 - 4 } & \multicolumn{3}{c}{ Replikasi } & & \\
\cline { 2 - 4 } & $\mathbf{1}$ & $\mathbf{2}$ & $\mathbf{3}$ & 28.208 & 9.403 \\
\hline Kontrol (M0) & 9.612 & 9.221 & 9.375 & 23.036 & 7.679 \\
\hline Variabel 1 (MS1) & 7.762 & 7.465 & 7.809 & 21.802 & 7.267 \\
\hline Variabel 2 (MS2) & 7.235 & 7.618 & 6.949 & 18.833 & 6.278 \\
\hline Variabel 3 (MS3) & 6.095 & 6.441 & 6.297 & 18.280 & 6.093 \\
\hline Variabel 4 (MS4) & 5.777 & 6.268 & 6.235 & 91.354 & 36.720 \\
\hline
\end{tabular}

Keterangan :

M0 = Mortar dengan proporsi tanpa silica fume

MS1 $=$ Mortar dengan proporsi silica fume 3\% dari berat semen

MS2 = Mortar dengan proporsi silica fume $5 \%$ dari berat semen

MS3 = Mortar dengan proporsi silica fume 7\% dari berat semen

MS4 = Mortar dengan proporsi silica fume $10 \%$ dari berat semen

Hasil analisa statistik yang dilakukan secara manual terhadap data hasil pengujian daya serap air ditampilkan pada Tabel 3.

Tabel 3. Hasil analisa statistik manual terhadap data hasil pengujian daya serap air mortar

\begin{tabular}{lrrrr}
\hline \multicolumn{1}{c}{ Source Variation } & $\begin{array}{c}\text { Sum of } \\
\text { Squares }\end{array}$ & $\begin{array}{c}\text { Degrees Of } \\
\text { Freedom }\end{array}$ & Mean Squares & \multirow{2}{*}{ F $_{\mathbf{0}}$} \\
\hline Between treatments & 21.17 & 4 & 5.292 & 90.70 \\
Error & 1.58 & 10 & 0.058 & \\
Total & 21.75 & 14 & & \\
\hline
\end{tabular}

Seperti yang dapat dilihat pada Tabel 3, nilai $\mathrm{SS}_{\text {Treatments }}$ atau total koreksi terhadap antara perlakuan sebesar 21.17 dengan derajat kebebasan sebesar 4 (a-1) dan rata-rata total koreksi atau $\mathrm{MS}_{\text {Treatment }}$ sebesar 5.292. Untuk kesalahan dalam perlakuan didapat nilai $\mathrm{SS}_{\mathrm{E}}$ atau kesalahan total koreksi sebesar 1.58 dengan derajat kebebasan sebesar $10(\mathrm{~N}-a)$ dan rata-rata total koreksi sebesar 0.058 . Dari perhitungan didapatkan nilai $\mathrm{F}_{0}$ atau $\mathrm{F}$ hitung sebesar 90.70 . Hasil perhitungan secara manual tersebut kemudian dibandingkan dengan output program MINITAB 14 yang diperlihatkan pada Tabel 4 .

Terlihat pada Tabel 4 bahwa nilai $\mathrm{F}$ yang diberikan oleh program Minitab 14 sama dengan nilai $\mathrm{F}$ hasil perhitungan manual, yakni sebesar 90,70. Selanjutnya nilai $F$ yang diperoleh secara manual dan program $\left(\mathrm{F}_{0}\right)$ ini disebut dengan $\mathrm{F}$ hitung dan kemudian dibandingkan dengan $\mathrm{F}$ tabel. Nilai $\mathrm{F}$ tabel sendiri didapatkan dari tabel $F$-distribution. Nilai $\mathrm{F}$ tabel ini diperoleh dengan menggunakan tingkat signifikansi $95 \%(\alpha=0.05)$, dengan derajat kebebasan total koreksi perlakuan sebesar 4 (a-1) dan derajat kebebasan kesalahan total koreksi dalam perlakuan sebesar $10(\mathrm{~N}-a)$. Untuk itu didapatkan nilai $\mathrm{F}$ tabel $\left(\mathrm{F}_{0.05,4,10}\right)$ sebesar 3,48. Karena nilai $\mathrm{F}$ hitung lebih besar dari $\mathrm{F}$ tabel, maka sesuai dengan Persamaan 7 dapat disimpulkan bahwa terdapat perbedaan yang signifikan diantara nilai rata-rata perlakuan. Atau dengan kata lain, penambahan silica fume sebagai pengganti sebagian semen berpengaruh signifikan dalam menurunkan daya serap air mortar. 
Tabel 4. Output program Minitab 14 mengenai hasil uji daya serap air

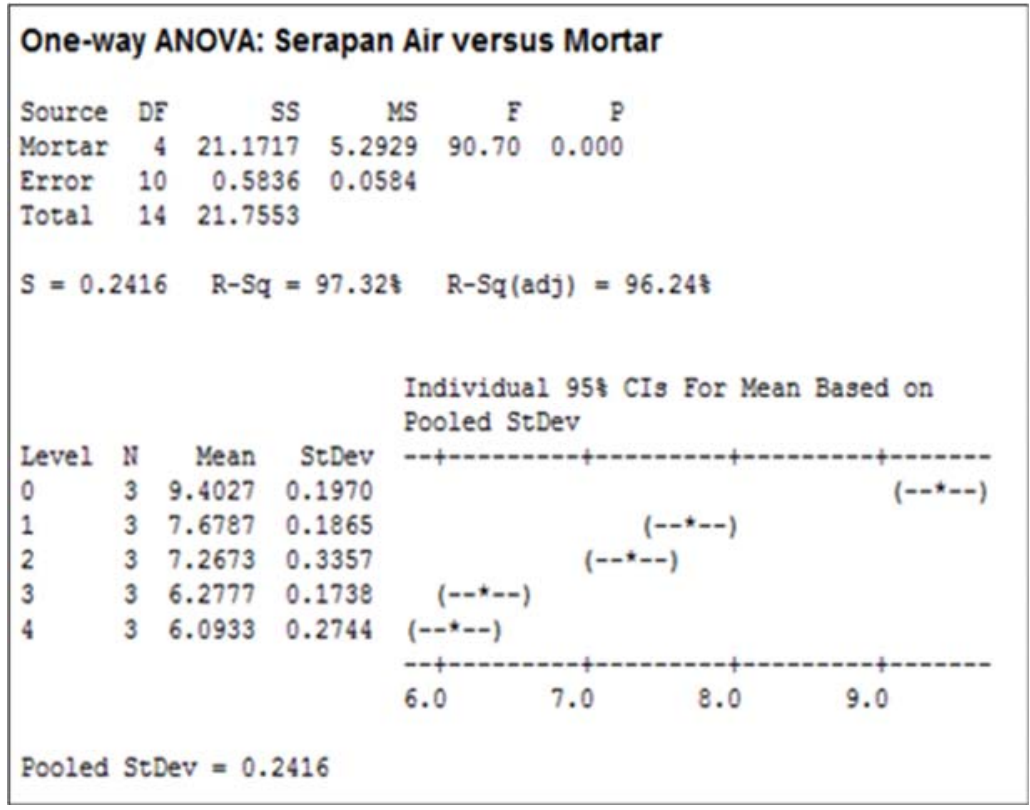

Selanjutnya, untuk melengkapi hasil ANOVA ini dilakukan uji lanjutan (pairwise test) dengan uji Dunnet, Tukey dan Fisher. Tetapi mengingat terbatasnya halaman, maka hasil lengkap dari ketiga test tersebut tidak dibahas disini. Hanya sedikit dibahas hasil pengelompokan yang dilakukan menggunakan metode Fisher seperti yang terlihat pada Tabel 5. Hasil pengelompokkan yang dilakukan dengan metode Fisher menunjukan bahwa sebenarnya variabel 1 dan variabel 2 tidak berbeda secara signifikan, demikian pula antara variabel 3 dan 4 . Sehingga variabel 1 dan 2, oleh metode Fisher, dimasukan kedalam satu kelompok, yakni kelompok B. Hal yang sama terjadi pada variabel 3 dan 4 yang disatukan kedalam kelompok C. Sehingga hasil akhir uji pengelompokan Fisher ini hanya mengelompokan kelima variabel ini kedalam 3 kelompok.

Tabel 5. Hasil pengelompokkan variabel pada uji daya serap air mortar dengan metode Fisher

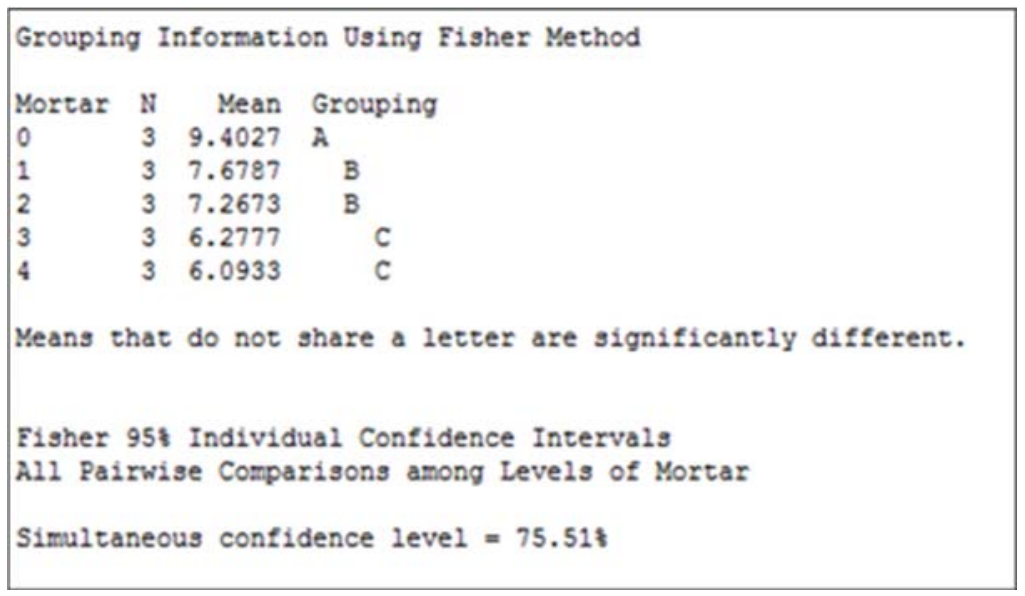

\subsection{Hasil Pengujian pH Mortar.}

Pengujian $\mathrm{pH}$ mortar dilakukan untuk mengetahui sejauhmana pengaruh penambahan silica fume pada campuran mortar terhadap tingkat keasaman atau $\mathrm{pH}$ mortar yang direndam dalam air laut 
selama 28 hari. Pengujian ini dilakukan di Laboratorium Kimia Analitik Fakultas MIPA Universitas Mataram. Rata-rata hasil pengujian $\mathrm{pH}$ mortar untuk masing-masing variabel dan kontrol dapat dilihat pada Gambar 2.

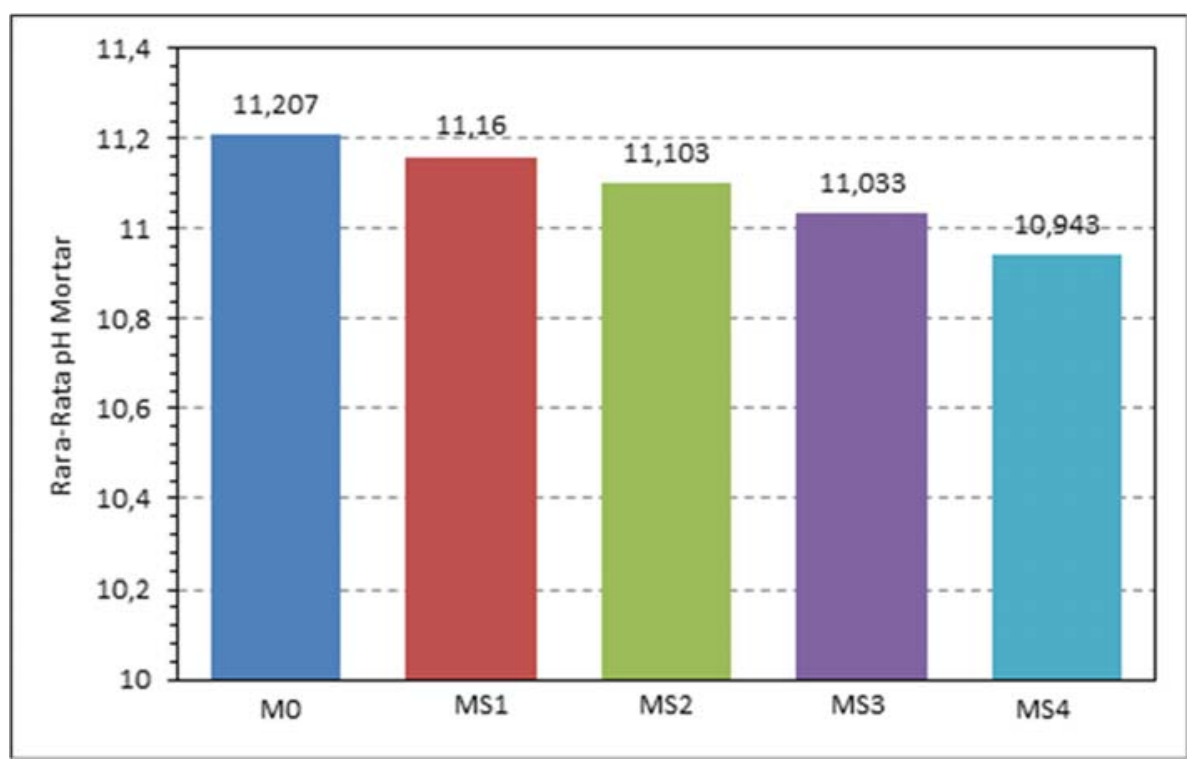

Gambar 2. Rata-rata hasil pengujian $\mathrm{pH}$ mortar untuk masing-masing variabel penelitian

Secara sekilas terlihat pada Gambar 2 bahwa penambahan silica fume akan menurunkan $\mathrm{pH}$ mortar. Secara berturut-turut nilai pH untuk MS1, MS2, MS3, MS4 adalah sebesar 11.16, 11.103, 11.033, 10.943 lebih kecil dari $\mathrm{pH}$ mortar normal (M0) yang dijadikan sebagai kontrol, yakni sebesar 11.207. Adapun persentase penurunan $\mathrm{pH}$ akibat adanya penambahan silica fume dari setiap variabel terhadap M0 secara berturut-turut sebesar $0.004 \%, 0.009 \%, 0.015 \%$ dan $0.024 \%$. Penurunan ini sekilas terlihat tidak terlalu signifikan. Penurunan terbesar hanya sebesar $0.024 \%$, sehingga sifat dari keseluruhan mortar tersebut masih termasuk bersifat basa. Nilai $\mathrm{pH}$ dikatakan asam apabila nilainya kurang dari 7. Nilai $\mathrm{pH}$ untuk semua variabel dan kontrol dalam penelitian ini masih dalam rentang nilai yang bisa diterima (acceptable value) seperti yang dikatakan oleh Sugiyarto (2011) yang hasil eksperimennya menyimpulkan bahwa nilai $\mathrm{pH}$ yang baik untuk menahan serangan yang diakibatkan oleh zat asam yang bisa mengakibatkan kerusakan seperti korosi adalah lebih dari 9. Meskipun secara sekilas terlihat bahwa nilai $\mathrm{pH}$ semua level faktor diatas hampir mirip, namun untuk menyatakan bahwa tidak ada perbedaan yang signifikan diantara variabel-variabel tersebut harus dilakukan pengujian statistik terlebih dahulu. Untuk keperluan tersebut maka data lengkap hasil pengujian, seperti yang ditampilkan pada Tabel 6, harus dianalisa dengan metode ANOVA terlebih dahulu.

Tabel 6. Hasil pengujian $\mathrm{pH}$ mortar

\begin{tabular}{lccccc}
\hline \multirow{2}{*}{ Variabel } & \multicolumn{3}{c}{ Nilai pH Mortar } & \multirow{2}{*}{ Total } & \multirow{2}{*}{ Rata-Rata } \\
\cline { 2 - 4 } & \multicolumn{3}{c}{ Replikasi } & & \\
\cline { 2 - 4 } & 11.14 & 11.29 & 11.19 & 33.62 & 11.207 \\
\hline Kontrol (M0) & 11.16 & 11.16 & 11.16 & 33.48 & 11.160 \\
\hline Variabel 1 (MS1) & 11.11 & 11.10 & 11.10 & 33.31 & 11.103 \\
\hline Variabel 2 (MS2) & 11.00 & 11.05 & 11.05 & 33.1 & 11.033 \\
\hline Variabel 3 (MS3) & 10.88 & 10.98 & 10.97 & 32.83 & 10.943 \\
\hline Variabel 4 (MS4) & \multicolumn{7}{c}{} & 166.34 & 55.447 \\
\hline
\end{tabular}


Hasil analisa statistik yang dilakukan secara manual terhadap data hasil uji $\mathrm{pH}$ mortar ditampilkan pada Tabel 7, sementara output program Minitab 14 ditampilkan pada Tabel 8. Berdasarkan hasil perhitungan yang hasilnya diperlihatkan pada Tabel 7, diketahui bahwa nilai $\mathrm{SS}_{\mathrm{E}}$ atau kesalahan total koreksi dalam perlakuan adalah sebesar 0.0195 dengan derajat kebebasan sebesar $10(\mathrm{~N}-a)$ dan ratarata total koreksi sebesar 0.001947. Nilai $\mathrm{SS}_{\text {Treatments }}$ atau total koreksi terhadap antara perlakuan sebesar 0.1302 dengan derajat kebebasan sebesar 4 (a-1) dan rata-rata total koreksi atau $\mathrm{MS}_{\text {Treatment }}$ sebesar 0.033 . Dari perhitungan selanjutnya didapatkan nilai $\mathrm{F}_{0}$ atau $\mathrm{F}$ hitung sebesar 16.724. Dari tabel F-distribution diperoleh nilai $\mathrm{F}$ tabel $\left(\mathrm{F}_{0.05,4,10}\right)$ sebesar 3.48. Hal ini berarti bahwa nilai $\mathrm{F}$ hitung lebih besar dari $\mathrm{F}$ tabel. Berdasarkan Persamaan 7, apabila nilai $\mathrm{F}$ hitung lebih besar dibandingkan nilai $\mathrm{F}$ tabel, maka Hipotesis nol $\left(\mathrm{H}_{0}\right)$ yang menyatakan bahwa rata-rata semua variabel adalah sama harus ditolak. Hal ini berarti, hipotesis alternatifnya $\left(\mathrm{H}_{1}\right)$ harus diterima yang menyatakan bahwa terdapat perbedaan yang signifikan antara nilai rata-rata level faktor atau antara variabel-variabel penelitian. Hal ini berarti, penambahan silica fume berpengaruh signifikan dalam menurunkan $\mathrm{pH}$ mortar.

Tabel 7. Hasil analisa statistik terhadap pH mortar secara manual.

\begin{tabular}{lrrrr}
\hline \multicolumn{1}{c}{ Source Variation } & $\begin{array}{c}\text { Sum Of } \\
\text { Squares }\end{array}$ & $\begin{array}{c}\text { Degrees Of } \\
\text { Freedom }\end{array}$ & Mean Squares & F $_{\mathbf{0}}$ \\
\hline Between treatments & 0.1302 & 4 & 0.033 & 16.724 \\
Error & 0.0195 & 10 & 0.001947 & \\
Total & 0.1479 & 14 & & \\
\hline
\end{tabular}

Tabel 8. Hasil analisa statistik $\mathrm{pH}$ mortar dengan program Minitab

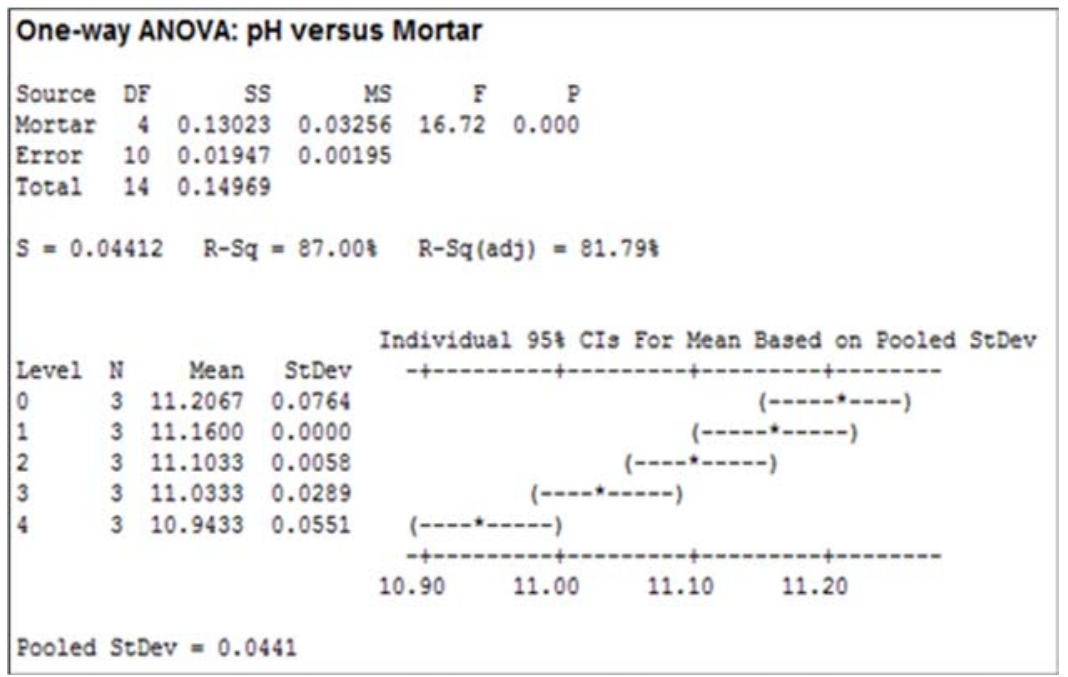

Hasil pengelompokan (grouping) yang dilakukan dengan metode Fisher yang ditampilkan pada Tabel 9 memperlihatkan bahwa ada empat kelompok variabel yaitu kelompok A, B, C, dan D. Kontrol (M0) dimasukan kedalam kelompok A. Sementara variabel 1 (MS1) masuk kedalam dua kelompok, bisa A atau B. Hal yang sama terjadi pada variabel 2 yang bisa masuk kelompok B atau kelompok C. Variabel 3 masuk kedalam kelompok C dan variabel 4 masuk kedalam kelompok D. Hal ini mempunyai makna bahwa tidak terdapat perbedaan yang signifikan antara variabel 1 dengan kontrol dan antara variabel 1 dengan variabel 2 . Sehingga bisa kemudian dijustifikasi bahwa variabel 1 sama saja dengan kontrol dan variabel 2 sama saja dengan variabel 3. Dengan demikian dapat dikatakan bahwa berdasarkan nilai $\mathrm{pH}$, penambahan silica fume sebesar $3 \%$ tidak berarti. Demikian pula dengan penambahan sebesar $7 \%$ sebaiknya tidak dilakukan, cukup hanya dengan menambahkan $5 \%$ silica fume akan memberikan pengaruh yang sama dengan penambahan sebesar $7 \%$.

VOLUME 12 NO. 1, FEBRUARI 2016 | 19 
Tabel 9. Hasil pengelompokan variabel pada uji pH mortar dengan metode Fisher

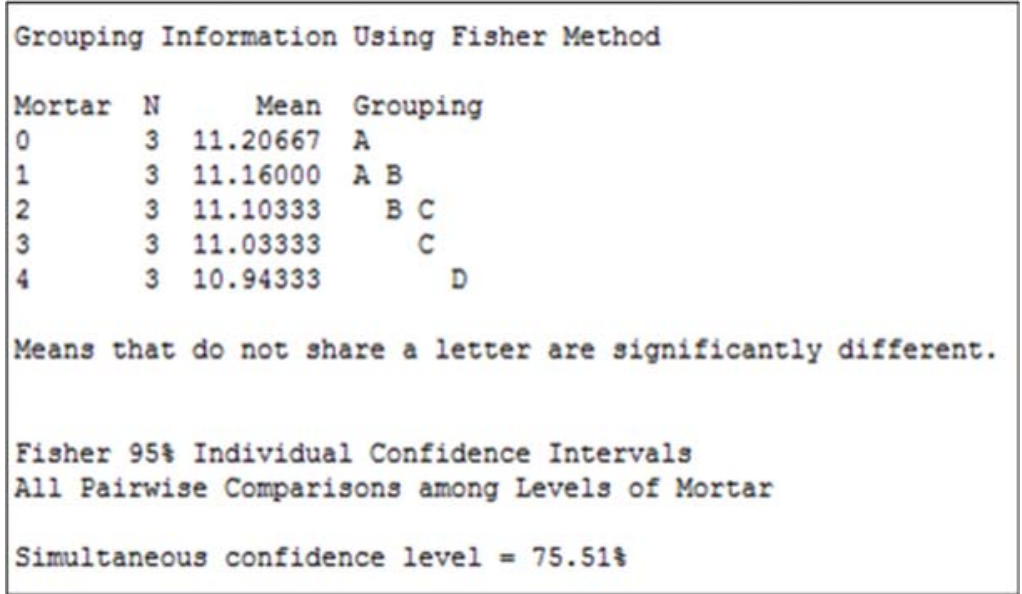

\subsection{Kuat Tekan Mortar}

Pengujian kuat tekan mortar dilakukan menggunakan alat Compressing Testing Machine (CTM). Rata-rata hasil pengujian kuat tekan mortar untuk masing-masing variabel dan kontrol dapat dilihat pada Gambar 3.

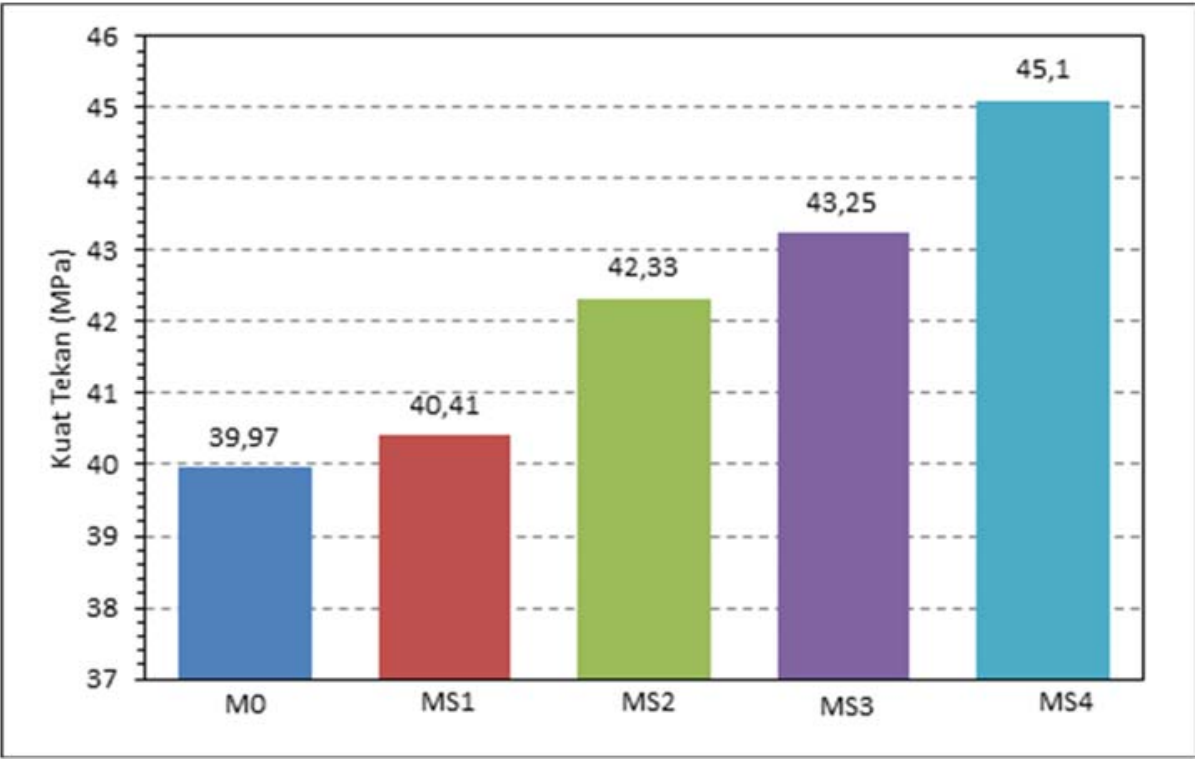

Gambar 3. Rata-rata hasil pengujian kuat tekan mortar untuk masing-masing variabel penelitian

Seperti yang dapat dilihat dengan jelas pada Gambar 3, rata-rata kuat tekan mortar normal tanpa campuran silica fume adalah 39,97 Mpa. Sementara kuat tekan rata-rata mortar dengan campuran silica fume secara berturut-turut adalah 40,41 $\mathrm{MPa}, 42,33 \mathrm{MPa}, 43,25 \mathrm{MPa}$ dan 45,10 $\mathrm{MPa}$ untuk variabel 1 sampai 4. Terlihat disini bahwa kuat tekan mortar berbanding lurus dengan peningkatan kandungan silica fume yang dicampurkan. Kuat tekan mortar tertinggi dicapai pada mortar MS4 dengan proporsi silica fume $10 \%$ dari berat semen dengan nilai kuat tekan rata-rata sebesar 45.10 MPa. Hal ini sesuai dengan kesimpulan penelitian yang dilakukan oleh Ilham (2005) dan Afif (2013) yang menyatakan bahwa penggunaan silica fume yang memiliki kandungan silika yang tinggi, kandungan karbon yang rendah, luas permukaan yang besar, dan ukuran partikel yang halus dan 20 | JURNAL REKAYASA SIPIL 
amorfus sehingga reaksi pozzolan yang terjadi lebih cepat, dapat meningkatkan kuat tekan mortar. Peningkatan kuat tekan yang terjadi berturut-turut adalah sebesar $1,10 \%, 5,90 \%, 8,20 \%$, dan 12,84 $\%$ untuk variabel 1 sampai 4 . Namun demikian, terlihat dengan cukup jelas pada Gambar 3 bahwa penambahan $3 \%$ silica fume hanya mampu meningkatkan kuat tekan yang relatif kecil, yakni dari 39,97 MPa ke 40,41 Mpa, atau hanya sebesar 1.10\%. Tetapi untuk lebih memastikan bahwa apakah ada perbedaan yang signifikan atau tidak, maka perlu dilakukan analisa statistik. Data lengkap mengenai hasil pengujian kuat tekan untuk diolah secara statistik disajikan pada Tabel 10. Sementara hasil analisa statistik yang dilakukan secara manual terhadap data hasil uji tekan ditampilkan pada Tabel 11.

Tabel 10. Hasil pengujian kuat tekan mortar

\begin{tabular}{|c|c|c|c|c|c|c|c|}
\hline \multirow{3}{*}{ Faktor Level } & \multicolumn{5}{|c|}{ Kuat Tekan (MPa) } & \multirow{3}{*}{ Total } & \multirow{3}{*}{$\begin{array}{c}\text { Rata-Rata } \\
\text { (MPa) }\end{array}$} \\
\hline & \multicolumn{5}{|c|}{ Replikasi } & & \\
\hline & 1 & 2 & 3 & 4 & 5 & & \\
\hline Kontrol (M0) & 38.52 & 43.09 & 38.40 & 43.57 & 36.27 & 199.85 & 39.97 \\
\hline Variabel 1 (MS1) & 40.17 & 39.04 & 41.32 & 41.53 & 39.98 & 202.04 & 40.41 \\
\hline Variabel 2 (MS2) & 42.46 & 41.36 & 42.07 & 41.86 & 43.92 & 211.47 & 42.33 \\
\hline Variabel 3 (MS3) & 43.48 & 43.94 & 43.81 & 41.92 & 43.12 & 216.27 & 43.25 \\
\hline \multirow[t]{2}{*}{ Variabel 4 (MS4) } & 44.08 & 46.60 & 46.28 & 44.60 & 43.97 & 225.53 & 45.10 \\
\hline & & & & & & 1057.16 & 211.06 \\
\hline
\end{tabular}

Tabel 11. Hasil analisa statistik kuat tekan mortar secara manual.

\begin{tabular}{lrrrr}
\hline \multicolumn{1}{c}{ Source Variation } & $\begin{array}{c}\text { Sum Of } \\
\text { Squares }\end{array}$ & $\begin{array}{c}\text { Degrees Of } \\
\text { Freedom }\end{array}$ & Mean Squares & \multirow{2}{*}{ Fo } \\
\hline Between treatments & 88.78 & 4 & 22.20 & 7.68 \\
Error & 57.77 & 20 & 2.89 & \\
Total & 146.55 & 24 & & \\
\hline
\end{tabular}

Seperti yang dapat dilihat pada Tabel 11, nilai $\mathrm{SS}_{\text {Treatments }}$ dan $\mathrm{MS}_{\text {Treatment }}$ adalah masing-masing sebesar 88.78 dan 22.20. Nilai $\mathrm{SS}_{\mathrm{E}}$ atau kesalahan total koreksi dalam perlakuan diperoleh sebesar 57,77 dan rata-rata total koreksi sebesar 2.89. Selanjutnya didapatkan nilai $\mathrm{F}_{0}$ atau $\mathrm{F}$ hitung sebesar 7,68. Hasil running program MINITAB 14 pada Tabel 12 memperlihatkan nilai F yang sama dengan nilai $\mathrm{F}$ dengan perhitungan manual. Selanjutnya dari tabel $\mathrm{F}$ distribution dapatkan nilai $\mathrm{F}$ tabel $\left(\mathrm{F}_{0.05,4,20}\right)$ sebesar 2.87. Terlihat dengan jelas bahwa nilai $\mathrm{F}$ hitung lebih besar daripada $\mathrm{F}$ tabel yang bermakna bahwa hipotesis nol harus ditolak dan menerima hipotesis alternatifnya yang menyatakan bahwa terdapat perbedaan yang signifikan diantara variabel-variabel penelitian yang diteliti. Secara teknis hal ini berarti bahwa penambahan silica fume sebagai pengganti sebagian semen berpengaruh signifikan dalam meningkatkan kuat tekan mortar.

Hasil pengelompokkan yang diberikan oleh uji Fisher's yang ditampilkan pada Tabel 12 menunjukan bahwa ada empat kelompok level atau variabel yaitu kelompok A, B, C, dan D. Dimana mortar normal atau kontrol (M0) masuk di dalam kelompok D, variabel 1 (MS1) masuk di dalam kelompok $\mathrm{C}$ dan D, variabel 2 (MS2) masuk di dalam kelompok B dan C, variabel 3 (MS3) masuk di dalam kelompok A dan B, serta variabel 4 (MS4) masuk kedalam kelompok A. Bila diinterpretasikan lebih jauh dapat dikatakan bahwa penambahan silica fume sebesar 3\% tidak efektif dalam memperbaiki kekuatan tekan mortar karena hasilnya tidak terlalu signifikan. Penambahan sebesar 5\% dan 7\% juga tidak memberikan perbedaan yang signifikan, sehingga cukup diberi 5\% saja. Sementara itu, pemberian tambahan silica fume sebesar $10 \%$ tidak mampu meningkatkan kuat tekan secara signifikan dibandingkan dengan proporsi $7 \%$. Sehingga tidak perlu diberikan tambahan silica fume sebesar $10 \%$. 
Tabel 12. Hasil pengelompokan variabel pada uji kuat tekan mortar dengan uji Fisher

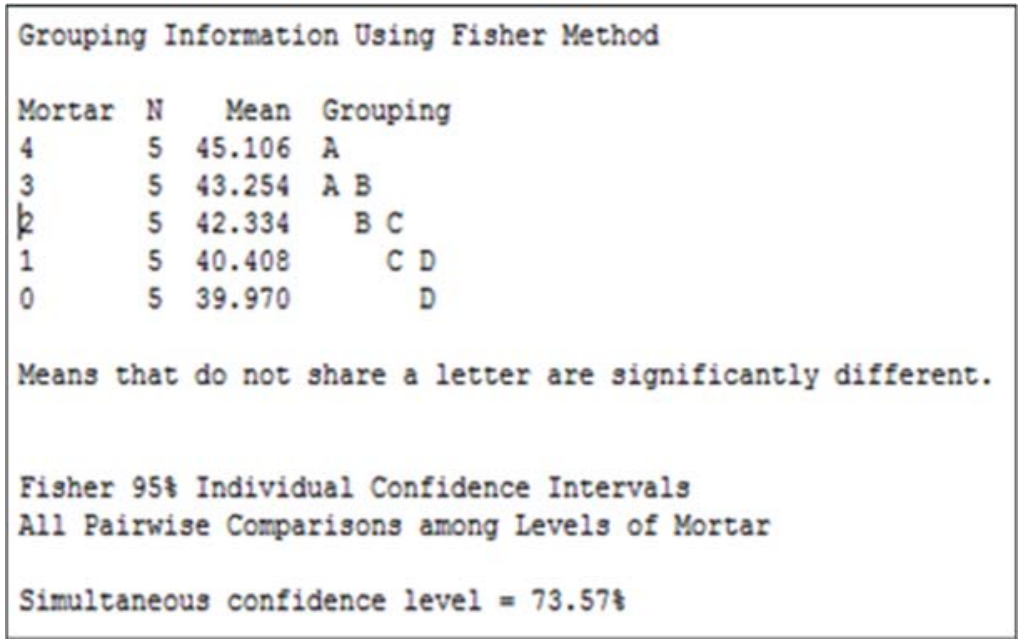

\section{KESIMPULAN DAN SARAN}

\subsection{Kesimpulan}

Secara umum dari hasil penelitian, pengujian, analisa data dan pembahasan yang dilakukan dalam penelitian ini dapat disimpulkan bahwa:

1) Penambahan bahan pozolan silica-fume mampu memperbaiki membuat mortar menjadi lebih kedap air yang ditandai dengan menurunnya daya serap air seiring dengan bertambahnya proporsi silica-fume sebagai pengganti sebagian semen (partial cement replacement). Terjadi penurunan daya serap air sebesar $18,335 \%$ ketika mortar diberi tambahan silica fume sebesar 3\% dari berat semen. Selanjutnya terjadi penurunan secara konstan sebesar 22,716\%, $33,234 \%$ dan 35,202\% ketika ditambahkan silica fume sebesar 5, 7 dan 10\%. Dari hasil ANOVA diperoleh nilai $\mathrm{F}$ tabel $\left(\mathrm{F}_{0.05,4,10}\right)$ sebesar 3,48. Nilai ini lebih kecil dibandingkan dengan nilai $\mathrm{F}$ hitung $(90,70)$, maka dapat disimpulkan bahwa terdapat perbedaan yang signifikan diantara nilai rata-rata perlakuan.

2) Penambahan silica fume juga mampu menurunkan $\mathrm{pH}$ mortar. Tetapi pada penelitian ini, meskipun $\mathrm{pH}$ mortar menurun dengan bertambahnya proporsi silica fume, kondisi $\mathrm{pH}$ nya masih dalam keadaan basa yang relatif aman bagi tulangan yang dilindungi oleh mortar. Adapun persentase penurunan $\mathrm{pH}$ akibat adanya penambahan silica fume dari setiap variabel terhadap M0 secara berturut-turut sebesar $0,004 \%, 0,009 \%, 0,015 \%$ dan $0,024 \%$. Penurunan ini sekilas terlihat tidak terlalu signifikan. Tetapi hasil ANOVA menunjukan bahwa nilai $\mathrm{F}_{0}$ atau $\mathrm{F}$ hitung $(16,724)$ lebih besar dibandingkan dengan nilai $\mathrm{F}$ tabel $\left(\mathrm{F}_{0.05,4,10}\right)$ sebesar 3,48 yang mengindikasikan bahwa terdapat perbedaan yang signifikan antara nilai rata-rata level faktor atau variabel penelitian.

3) Untuk sifat mekanik, terlihat bahwa kuat tekan mortar berbanding lurus dengan peningkatan kandungan silica fume yang dicampurkan. Rata-rata kuat tekan mortar normal tanpa campuran silica fume adalah 39,97 Mpa. Sementara kuat tekan rata-rata mortar dengan campuran silica fume secara berturut-turut adalah 40,41 MPa, 42,33 MPa, 43,25 MPa dan 45,10 MPa untuk variabel 1 sampai 4. Peningkatan kuat tekan yang terjadi berturut-turut adalah sebesar $1,10 \%, 5,90 \%, 8,20 \%$, dan $12,84 \%$ untuk variabel 1 sampai 4 . Nilai $F$ hitung $(7,68)$ lebih besar dari nilai $\mathrm{F}$ tabel $(2,87)$ yang bermakna bahwa hipotesis nol harus ditolak dan menerima hipotesis alternatifnya yang menyatakan bahwa terdapat perbedaan yang signifikan diantara variabel-variabel penelitian yang diteliti. Secara teknis hal ini berarti 
bahwa penambahan silica fume sebagai pengganti sebagian semen berpengaruh signifikan dalam meningkatkan kuat tekan mortar.

\subsection{Saran}

Dari penelitian yang telah dilakukan, adapun saran-saran yang dapat diberikan adalah sebagai berikut:

1) Dalam proses uji konsistensi normal dan setting time sebaiknya dilakukan dengan sangat teliti dan hati-hati dalam menggunakan alat vicat agar diperoleh hasil yang akurat dan terhindar dari getaran.

2) Dari ketiga parameter yang diuji; daya serap air, $\mathrm{pH}$ dan kuat tekan, terlihat bahwa proporsi silica fume yang dicampurkan masih memungkinkan untuk ditingkatkan karena grafiknya masih berbentuk linear. Artinya proporsi yang optimum sebenarnya belum ditemukan dalam penelitian ini. Ini adalah fakta yang menarik untuk dijadikan sebagai bahan kajian lanjutan.

3) Untuk penelitian lanjutan disarankan untuk menggunakan inkremental peningkatan proporsi campuran silica fume sebesar $5 \%$ dan proporsi maksimum lebih dari $10 \%$, misalnya dengan inkremental 0, 5, 10, 15 dan 20 persen.

\section{REFERENSI}

Afif, 2013, Pengaruh Penambahan Silika Fume dan Superplasticizer dengan Pemakaian Semen Type PPC dan Type PCC Terhadap Peningkatan Mutu Beton, Tugas Akhir, Jurusan Teknik Sipil, Universitas Negeri Semarang, Semarang.

Ilham, A., 2005, Pengaruh Sifat-Sifat Fisik dan Kimia Bahan Pozzolan Beton Kinerja Tinggi, Media Komunikasi Teknik Sipil Jurusan Teknik Sipil UII, Vol. 13, No. 3, Edisi XXXIII.

Kuehl, R. O., Design of Experiment: Statistical Principles of Research Design and Analysis, Second Edition (Brooks/Cole Publishing, USA 2000).

Samekto, W., Rahmadiyanto, C., 2001, Teknologi Beton, Kanisius, ISBN: 979-672-564-9, Yogyakarta.

Sugiyarto, J., 2011, Pengaruh Susut Terkekang Repair Mortar Dengan Bahan Tambah Polimer Terhadap Kecendrungan Deliminasi, Tugas Akhir, Jurusan Teknik Sipil Fakultas Teknik, Universitas Sebelas Maret Surakarta, Surakarta.

Wackerley, D.D., Mendenhall, W., Scheaffer, R. L., (2008), Mathematical statistics with applications, Thompson Brooks/Cole, USA. Dalam: Fajrin, J., Zhuge, Y., Bullen, F., Wang, H., Flexural strength of sandwich panel with lignocellulosic composites intermediate layer-a statistic approach, International Journal of Protective Structures 2 (2011), p. 452-464. 